\title{
PENANAMAN NILAI BUDAYA MELALUI PERMAINAN ANAK DI KABUPATEN GARUT
}

\author{
Oleh Enden Irma Rachmawaty \\ Balai Pelestarian Sejarah dan Nilai Tradisional Bandung \\ Jln. Cinambo No. 136 Ujungberung Bandung \\ Email: EndenIrma@yahoo.com
}

Naskah diterima: 8 Januari 2010

Naskah disetujui: 12 Februari 2010

\begin{abstract}
Abstrak
Penelitian yang berjudul Penanaman Nilai Budaya melalui Permainan anak di Kabupaten Garut ini, bertujuan mengkaji nilai-nilai budaya yang terkandung dalam permainan. Pengakajian nilai-nilai budaya ini menggunakan metode deskriptif analisis. Apabila kita amati tentang jenis-jenis permainan anak dewasa ini, keberadaannya sudah kurang diminati bahkan kurang mendapat perhatian dari masyarakat pemiliknya, namun bila kita mendalami unsur-unsur yang terkandung dalam permainan anak-anak tersebut, banyak sekali nilai-nilai filosofis dan kearifan lokal yang tertanam dalam permainan anak, nilai budaya tersebut salah satunya adalah bentuk ketahanan budaya. Selain itu dalam permainan anak-anak itu banyak sekali nilai-nilai pembelajaraan yang bersifat demokratis (keadilan dan penerapan sanksi bagi yang melanggar) dan untuk belajar memulai kehidupan sosial anak (nilai untuk kerjasama dan menumbuhkan hasrat untuk berpikir dan berstrategi) dan belajar menjadi seorang pemimpin.
\end{abstract}

Kata kunci: budaya, nilai, permainan anak.

This research entitled The Cultivation of Cultural Values through Childs Games in Garut District, aims to to examine the culture values contained that contained in child and. This culture values research is using an deskriftif analysis method. If we watch about the recent child games, its existance is alreadylossing the interst from its onner, but if we explore deeper the contained element on these chil games, there lot of philosphical values and the local wisdom embendded on it. And one of them is culture resilience. Aside from these child games have a lot of democratically learning values (justice and purishmaeat for the the ones who discovery) and to start the social living (cooperative values and growing ambition's to think and to from strategies) and also to learn to be a team leader.

Keywords: cultural, values, children games.

\section{A. PENDAhuluan}

Keberadaan kebudayaan tradisional di Indonesia, khusunya di Jawa Barat, saat ini sudah banyak mengalami degradasi yang cukup memprihatinkan.
Keprihatinan ini tampak dari perhatian masyarakat yang lebih cenderung pada masalah ekonomi, politik dan hukum. Selain itu, kurangnya publikasi yang dimuat dalam media masa baik cetak 
maupun elektronik. Dampak tersebut sangat terlihat dari minimnya atau kekurangtahuan masyarakat pada kebudayaan tradisional yang saat ini masih ada dalam kehidupan masyarakat.

Peranan pemerintah dan dukungan dari masyarakat pada kebudayaan tradisional sangat diperlukan, sebab tanpa peran dan dukungan tersebut. keberadaan kebudayaan tradisional nasibnya akan tetap berjalan di tempat. Pemerintah melalui lembaga-lembaga terkait harus dapat meningkatkan program kerja baik melalui bentuk sosialisasi, penelitian dan pelestarian kebudayaan tradisional. Begitu pula lembaga swadaya masyarakat harus ikut serta dan mendukung setiap program pemerintah tersebut.

Bentuk upaya yang perlu dilakukan oleh berbagai pihak adalah menjaga, melestarikan dan mengembangkan kebudayaan tradisional; atau melalui pelaksanaan pengkajian tentang berbagai unsur kebudayaan baik lokal maupun nasional. Melalui upaya ini, kebudayaan tradisional bangsa kita akan tetap terjaga dan akan tetap eksis dalam kehidupan masyarakat.

Masyarakat Indonesia termasuk masyarakat multietnik yang memiliki latar belakang yang cukup bervariasi dan satu sama lainnya berbeda. Setiap suku bangsa memiliki sejarah dan peradaban serta lingkungan geografis yang berbeda. Hal itulah yang mendasari adanya perbedaan kebudayaan tradisional di setiap daerahdi Indonesia.

Keanekaragaman budaya ini merupakan modal yang tak terhingga sebagai kekayaan budaya bangsa. Akan tetapi di sisi lain, keberagaman ini pun bisa mengandung potensi konflik yang tidak bisa dipandang ringan, bila tidak dicapai kesepakatan di antara masingmasing pendukung kebudayaan itu. Oleh sebab itu upaya penelitian tentang unsur-unsur budaya lokal saja belumlah cukup, melainkan perlu dibarengi dengan upaya pengungkapan isi atau maknanya.

Upaya pengungkapan isi dari setiap unsur budaya ini perlu dilakukan mengingat kebudayaan sarat dengan unsur-unsur simbolik yang tidak sertamerta dapat dimengerti dan difahami isinya, melainkan perlu upaya-upaya pengkajian dan interpretasi yang merujuk pada nilai-nilai budaya setempat. Dalam hal ini, upaya pengkajian dan pelestarian perlu dilakukan secara kontekstual, yaitu melihat dan menginterpretasikan suatu unsur kebudayaan dari kacamata pendukung kebudayaan itu sendiri.

Salah satu kebudayaan yang hingga kini masih ada adalah permainan tradisional, atau lazim juga disebut permainan rakyat. Dalam kebudayaan masyarakat, permainan anak-anak adalah bagian dari folklor. Istilah folklor diperkenalkan oleh salah seorang ilmuwan tentang kebudayaan etnik yang bernama William John Thomas, seorang ahli kebudayaan entik (antikuarian).

Folklor dapat dikatagorikan ke dalam tiga golongan besar, yaitu folklor lisan, folklor sebagian lisan, dan folklor bukan lisan. Golongan folklor bukan lisan dapat dibagi lagi atas material dan yang bukan material. Setiap golongan mempunyai beberapa genre atau jenis. Folklor lisan misalnya, terdiri atas bentuk-bentuk ujaran rakyat (logat, julukan, pangkat tradisional, dan gelar kebangsawanan), ungkapan tradisional (peribahasa, pepatah), teka-teki, cerita rakyat, dan nyanyian rakyat. 
Folklor sebagian lisan terdiri atas bentuk-bentuk keyakinan rakyat, permainan rakyat, teater rakyat, tari rakyat, adat-istiadat, upacara, pesta rakyat.

Folklor bukan lisan yang material terdiri atas bentuk-bentuk arsitektur rakyat, seni kriya rakyat, pakaian dan perhiasan tubuh tradisional, alat musik tradisional, alat permainan rakyat. Yang termasuk folklor bukan lisan yang bukan material antara lain: gerak isyarat tradisional, bunyi isyarat untuk komunikasi rakyat (kentongan, dll) dan musik rakyat. (Ensiklopedi Nasional Indonesia, 1989).

Pada umumnya permainan tradisional sebagai bagian dari folklor bukan lisan material sangat menonjolkan fungsi sosial. Ini dapat dilihat dari sifat-sifat permainan tradisional yang biasanya dilakukan di luar rumah atau di tempat terbuka dengan pelaku yang lebih dari satu orang. Demikian pula nilai-nilai sosialnya cukup menonjol, seperti nilai kerja sama, sportifitas, dan kompetitif. Karena sifatnya yang harus dimainkan di luar rumah, maka biasanya untuk melakukan permainan tradisional diperlukan halaman yang cukup luas atau tanah lapang. Adapun permainan baru, tanpa harus keluar rumah dan tanpa harus ada teman. Mereka bisa melakukan permainan di dalam rumah.

Ada beberapa perbedaan yang sangat mendasar antara jenis-jenis permainan tradisional dengan permainan modern. Kalau permainan tradisional lebih menonjolkan nilainilai sosial, maka permainan modern lebih bersifat individualis, karena mereka tidak memerlukan teman bermain untuk melangsungkan permainan ini. Permasalahannya adalah dengan semakin terpinggirkannya permainan tradisional, akankah nilainilai sosial dan nilai-nilai budaya yang terkandung di dalam permainan tradisional ikut musnah? Hal ini pula yang melatar-belakangi pentingnya dilakukan kegiatan atau penelitian permainan tradisional ini.

Dengan berdasar pada permasalahan yang telah diuraikan sebelumnya ada beberapa permasalahan yang perlu dijadikan inti kajian. Adapun permasalahan tersebut disusun dalam bentuk pertanyaan sebagai berikut:

1. Jenis-jenis permainan tradisional apa saja yang masih hidup dan pernah hidup, dan dilakukan oleh anak-anak di Kabupaten Garut?

2. Sejauh manakah pengetahuan anakanak tentang permainan tradisional di Kabupaten Garut. Apakah permainan-permainan tradisional itu kini masih dikenal oleh anak-anak di Kabupaten Garut ?

3. Jenis permainan apa saja yang saat ini masih dilakukan oleh anak-anak di Kabupaten Garut?

4. Faktor-faktor apa saja yang menyebabkan alasan mereka meninggalkan permainan-permainan tersebut?

5. Nilai-nilai budaya apa saja yang terkandung di dalam permainan tradisional tersebut?

Tujuan umum yang ingin dicapai dari penelitian permainan tradisional ini adalah untuk mengkaji nilai-nilai budaya yang terkandung dalam permainan tradisional yang ada dan pernah ada di Kecamatan Malangbong, Kabupaten Garut, dalam rangka upaya melestarikan budaya tradisional. 
Adapun yang menjadi tujuan khususnya di antaranya:

1. Hasil dan pengkajian ini diharapkan dapat mengungkapkan nilainilai budaya yang terkandung di dalam permainan tradisional, khususnya permainan anak-anak.

2. Hasil ini diharapkan bisa menjadi bahan informasi bagi pihak-pihak yang berkepentingan dengan keberadaan kebudayaan tradisional, khususnya yang berkenaan dengan permainan tradisional.

Metode adalah sebuah cara dalam penelitian untuk mengarahkan agar tidak menyimpang dari permasalahan yang telah dirumuskan sebelumnya. Adapun metode yang akan digunakan dalam penelitan ini adalah metode deskriptif. Metode deskriptif ini adalah sebuah metode penelitan yang dapat menggambarkan data pada saat ini. Adapun teknik yang akan digunakan adalah teknik observasi dan wawancara.

Teknik observasi diperlukan untuk melihat dan mengamati secara langsung peragaan permainan tradisional yang dilakukan oleh anak-anak di lokasi penelitian. Dengan mengamati secara langsung, maka deskripsi tentang permainan tradisional akan dapat dipaparkan dengan lebih baik dan akurat.

Teknik wawancara digunakan selain untuk mengetahui permainanpermainan tradisional, juga untuk memperoleh berbagai data dan informasi yang berkaitan dengan pemahaman warga masyarakat mengenai permainan tradisional dimaksud. serta untuk mengetahui sejauh mana pengetahuan masyarakat, khususnya anak-anak mengenai permainan tradisional.
Wawancara dilakukan dengan informan terpilih (purposive sampling) dengan pertimbangan bahwa informan tersebut memahami secara mendalam mengenai berbagai aspek, khususnya yang berkaitan dengan tradisi-tradisi masyarakat setempat. Informan kunci yang kami wawancarai merupakan salah satu tokoh yang mempunyai perhatian tinggi pada seni budaya khususnya budaya tradisional Selain beliau itu tokoh dalam bidang budaya juga salah seorang pejabat struktural, tepatnya sebagai kepala seksi kesenian dan kebudayaan di Kantor Kecamatan Malangbong. Selanjutnya wawancara juga dilakukan dengan beberapa orang anak yang mengetahui tentang permainan tradisional anak-anak setempat. Wawancara dilakukan dengan menggunakan pedoman wawancara yang bersifat terbuka, dan memberikan kesempatan seluas-luasnya kepada informan untuk menyampaikan buah pikirannya.

\section{B. HASIL DAN BAHASAN}

\section{Letak Geografis dan Keadaan Alam}

Kabupaten Garut adalah salah satu daerah yang termasuk ke dalam wilayah Propinsi Jawa Barat. Secara administratif wilayah tersebut dibatasi oleh wilayah:

- sebelah barat berbatasan dengan Kabupaten Cianjur dan Kabupaten Bandung;

- sebelah utara berbatasan dengan Kabupaten Sumedang;

- sebelah timur berbatasan dengan Kabupaten Tasikmalaya dan

- sebelah selatan berbatasan dengan Samudera Indonesia. 
Dari data Statistik Kabupaten Garut, luas wilayah Kabupaten Garut adalah 3.066,88 kilometer persegi. Kabupaten Garut merupakan daerah lembah yang di sekelilingnya dikitari oleh pegunungan dengan ketinggian rata-rata 700-750 meter di atas permukaan laut. Daerah Garut beriklim tropis dengan suhu rata-rata 24 derajat selsius sampai 27 derajat selsius dan keadaan curah hujan per tahun rata-rata 2.589 milimeter.

Keadaan tekstur tanah Kabupaten Garut yang bergunung-gunung, beraliran sungai-sungai dan hamparan dataran rendah, berpengaruh pada tingkat kesuburan tanahnya. Dengan kondisi demikian, potensi wilayah Kabupaten Garut didominasi oleh usaha-usaha di bidang pertanian terutama tanaman perkebunan, tanaman pangan, peternakan, serta sumber daya hutan.

Berdasarkan karakteristik wilayah, Kabupaten Garut terbagi dalam dua wilayah, yaitu:

1. Wilayah Garut Utara terdiri atas dataran tinggi yang dapat dikatakan tanah persawahan terluas di Kabupaten Garut dan dataran tinggi dengan pegunungan dan perbukitan yang keadaannya sangat kritis terutama sepanjang daerah aliran Sungai Cimanuk.

2. Wilayah Kabupaten Garut Selatan mayoritas memiliki kemiringan tanah yang relatif curam dan dialiri 12 sungai yang mengalir ke arah selatan dan bermuara ke Samudera Indonesia. Kondisi demikian menjadikan daerah Garut Selatan bertanah labil sehingga pada musim penghujan daerah ini rawan longsor.
Kehidupan masyarakat Kabupaten Garut, secara umum menunjukkan ciri-ciri dan sifat tradisional agraris. Meskipun demikian, kehidupan masyarakatnya tidak dapat mengelak pengaruh arus modernisasi. Masyarakat Kabupaten Garut yang kreatif dan menjunjung kebersamaan dengan semangat gotong-royongnya, merupakan potensi dalam pelaksanaan pembangunan yang perlu dilestarikan dan ditingkatkan ke arah partisipasi yang positif menuju sasaran yang telah dirancang.

Dalam kehidupan sosial penduduk yang tersebar di pedesaanpedesaan tampak menunjukkan hubungan yang akrab, saling menghargai dan menjunjung tinggi kehidupan bersama. Gotong-royong terpelihara dan dilaksanakan dengan baik dalam kehidupan keluarga, ketetanggaan dan masyarakat pada umumnya. Kehidupan gotong-royong tampak dalam kegiatan bertani dan dalam aktivitas lainnya, baik menyangkut kepentingan pribadi, keluarga maupun kepentingan masyarakat.

\section{Deskripsi Permainan Anak-Anak}

Dalam bagian ini menguraikan tentang jenis-jenis permainan anakanak yang masih dikenal dan sekalisekali masih dimainkan oleh anak-anak di lokasi daerah penelitian yaitu daerah Kecamatan Malangbong, Kabupaten Garut. Berikut ini uraian masingmasing permainan.

\section{Congklak}

Permainan ini dilakukan biasanya untuk mengisi waktu luang, sehingga permainan ini bisa dilakukan setiap saat manakala ada waktu luang. Congklak adalah salah satu jenis 
permainan khususnya untuk perempuan, dimainkan berdua, menggunakan biji asem atau biji-bijian yang lain. Setiap orangnya memiliki 49 biji yang disimpan oleh masing-masing, tujuhtujuh dalam lubang yang berderet menjadi dua baris, pada setiap ujung baris ada lubang yang agak besar yang lazim disebut indung (induk).

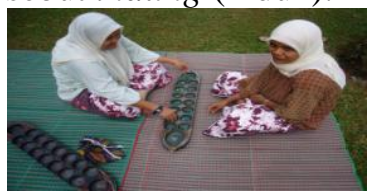

Penggemar permainan ini adalah kaum wanita, tua, muda, dan anak, tetapi bila tidak ada lawan bertanding, maka anak laki-laki suka diajak untuk bermain. Anak laki-laki "suka" bermain curang. Yang diinginkan anak lakilaki bukan keseriusan dalam permainannya, melainkan keceriaan dalam mencurangi anak perempuan. Permainan ini hanya dapat dilakukan oleh dua orang yang saling berhadapan. Lama permainan congklak tidak dibatasi oleh waktu, namun permainan berakhir manakala salah seorang kalah dengan jumlah biji congklaknya habis.

\section{Gatrik}

Permainan Gatrik merupakan permainan anak-anak laki-laki yang berumur kira-kira 8 sampai dengan 13 tahun, atau kebanyakan bagi anak-anak sekolah mulai dari kelas 3 (tiga) SD hingga kelas 6 (enam) SD. Permainan ini biasanya dilakukan pada waktuwaktu senggang, setelah mereka pulang sekolah.

Gatrik, berasal dari sebuah kirata atau akronim (dalam bahasa Sunda kirata merupakan singkatan kata, yaitu 'dikira-kira nyata' yang artinya diperkirakan nyata), yaitu 'dijaga' dan 'dijentrik', maka lahirlah kata gatrik.
Asal mula permainan Gatrik sendiri sangat sulit untuk diperkirakan berasal dari salah satu daerah di Jawa Barat, karena Gatrik sudah ada hampir di setiap daerah kabupaten di Jawa Barat dan Banten. Gatrik merupakan permainan anak laki-laki, menggunakan alat yang terbuat dari belahan bambu atau ranting yang ukurannya kurang lebih satu jengkal yang harus di betrikeun (dipukul) sejauh mungkin. Ada kemungkinan bahwa persebaran permainan Gatrik ini ada kaitannya dengan banyaknya kebun awi 'bambu' di seluruh daerah Jawa Barat, sebab Gatrik tak lepas dari permainan sebilah bambu yang mudah dimainkan dan sangat sederhana.

\section{Ngadu Bedil Lodong / Bagedor}

Bedil, artinya senjata api laras panjang; sedangkan lodong adalah batang bambu yang dipotong. Bedil Lodong merupakan permainan yang bahan dasarnya terbuat dari bambu gombong (bambu besar), sebagai bahan peledaknya yaitu dari minyak tanah atau karbit. Di daerah lain, permainan ini disebut dengan Ngadu Karbit.

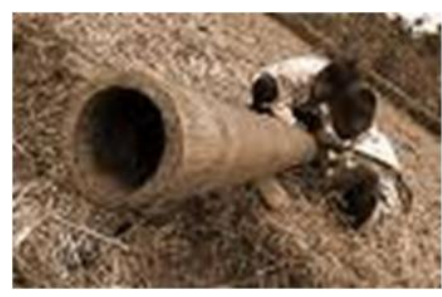

Istilah ngadu karbit atau adu karbit, bukan berarti karbitnya yang dipertandingkan, baunya atau banyaknya/ beratnya, melainkan suaranya yang keluar dari batang bambu atau batang pakis yang dibuat seolah-olah laras meriam dengan bahan 
peledaknya yaitu karbit. Ngadu Karbit ini di daerah Garut disebut ngadu bedil lodong atau bedil bagedor.

\section{Oray-orayan}

Oray-orayan adalah kata berulang dengan memakai akhiran an yang artinya menyerupai oray atau ular. Oray-orayan adalah salah satu jenis permainan anak. Permainan ini dikenal sejak dahulu kala, dan dikenal oleh hampir seluruh masyarakat Sunda di Jawa Barat, tentunya dengan sebutan yang berbeda-beda.

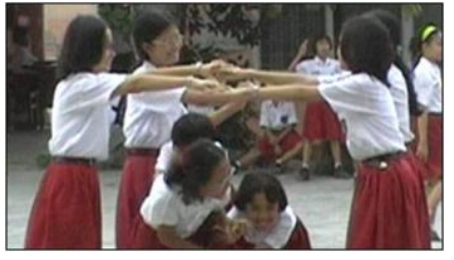

Para pelaku permainan ini umumnya adalah anak-anak, usia mereka biasanya berkisar antara 5 sampai 12 tahun. Jumlah pemain dalam permainan ini sekitar 7 anak sampai 20 anak, semakin banyak pengikut semakin baik karena akan lebih indah dilihat, bagaikan ular.

\section{Ngadu Panggal}

Ngadu Panggal merupakan jenis permainan tradisional anak-anak. Permainan ini dikenal oleh masyarakat luas, bukan hanya di Garut atau di Jawa Barat saja, melainkan sudah menasional. Panggal itu merupakan benda yang terbuat dari kayu dan paku, biasanya menggunakan kayu nangka, jambu, atau kayu lain yang keras.

Dalam permainan Ngadu Panggal ini biasanya dilakukan oleh dua atau lebih pemain. Dalam pelaksanannya jenis permainan ini saling puncuh (hantam) panggal masing-masing, biasanya panggal yang kena hantam kalau tidak belah akan berlubang. Permainan Ngadu Panggal ini muncul tanpa diketahui siapa pencetusnya dan dari mana asalnya.

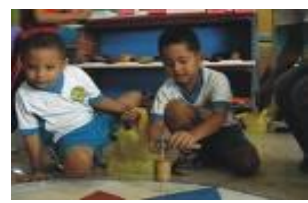

Dalam permainan ini juga tidak diketahui siapa yang pertama memainkannya dan berapa lama musim permainan ini berlangsung. Permainan ini bisa dilakukan sendiri-sendiri bisa juga berkelompok, tergantung kesepakatan dan jumlah pemain yang ada.

\section{Papanahan /Garis Kapur}

Permainan ini dilakukan oleh warga yang ada di sekitar Malangbong dengan tidak mengetahui asal muasal permainannya. Masyarakat terutama mengenal permaianan ini secara turuntemurun. Permainan ini dilaksanakan secara bergerombol atau banyak orang.

Para pemain dalam permainan ini kebanyakan adalah anak-anak, baik anak-anak perempuan maupun anak laki-laki. Usia para pemain biasanya berkisar antara 7 sampai 15 tahun. Permainan ini disebut dengan papanahan karena dalam pelaksanaannya menggunakan panah sebagai tanda yang harus dicari oleh si anak yang kebetulan kalah dalam sulit atau pengundian. Permainan Papanahan ini tidak banyak menggunakan peralatan atau perlengkapan, hanya kapur tulis yang digunakan untuk menandai arah panah, arah mereka yang bersembunyi. 
Sebelum bermain, para peserta berkumpul terlebih dahulu untuk melakukan pengundian. Pengundian dilaksanakan dengan cara hompimpah. Setelah selesai pengundian dan ada seorang yang kalah dalam pengundian atau suit, maka dialah yang mencari teman-temannya yang berlarian. Mereka yang berlarian sambil bersembunyi memberi tanda panah dengan kapur tulis tersebut sebagai tanda dimana mereka bersembumnyi. $\mathrm{Si}$ anak yang kalah, katakanlah yang menjadi kucing harus mencari temantemannya yang bersembunyi; tanda panah itulah sebagai petunjuk dimana mereka berada atau bersembunyi, karena tanda panah yang terakhir lah yang menunjukkan bahwa temantemannya berada di sekitar itu. Setelah itu barulah dia mencari temannya satu persatu sampai semua ditemukan. Dalam permainan ini tidak ada yang kalah atau menang. Tetapi yang ada adalah; siapa yang kena duluan itulah yang akan menjadi kucing. Selanjutnya berjalan seperti semula.

\section{Meong Bongkok}

Permainan Meong Bongkok merupakan suatu permainan anak-anak yang hanya ditemukan di daerah Cibatu Kabupaten Garut saja. Secara etimologis, nama permainan ini terdiri atas 2 kata, yaitu "meong" yang artinya harimau; dan kata bongkok yang artinya bungkuk.

Permainan Meong Bongkok (Harimau Bungkuk) merupakan permainan ketangkasan menggendong yang dilaksanakan secara berpasangan dan berkelompok. Setiap pemain harus mempunyai pasangan masing-masing untuk dijadikan maung yang mampu menggendong pasangannya.
Anak-anak di kampung berkumpul sambil mengisi kekosongan waktunya sebelum mereka berangkat ngaji di surau atau sehabis mereka membantu orang tua mengarit rumput. Biasanya mereka berkumpul antara sepuluh hingga dua belas orang, baik laki-laki maupun perempuan. Mereka sepakat untuk melakukan permainan Meong Bongkok. Untuk melakukan permainan Meong Bongkok biasanya diperlukan lahan yang cukup luas, karenanya mereka mencari lahan yang luas yang biasanya berada di samping rumah, lahan kebun yang kosong, atau sawah yang sudah kering karena kemarau. Lahan yang diperlukan untuk permainan ini kira-kira luasnya antara lebar 5 meter dan panjang 10 meter. Baik anak perempuan maupun laki-laki dalam permainan ini tidak ada pengecualian mereka dianggap sama (tidak ada anak bawang atau anak yang dikecualikan) asal bisa menggendong dan digendong. Permainan Meong Bongkok dilakukan kapan saja tidak mengenal waktu tertentu. Bilamana anak-anak berkumpul dan ada waktu kosong untuk melakukan permainan maka permainan Meong Bongkok ini dilakukan.

\section{Nilai-Nilai Budaya dalam Permainan Tradisional Bagi Masyarakat}

Disadari atau tidak, derasnya arus permainan anak produksi luar negeri secara perlahan menggeser permainan tradisional yang penuh dengan nilai-nilai kearifan lokal dan benteng budaya. Sementara konsistensi pemerintah memberikan dukungan dalam mempertahankan nilai-nilai tradisi masih setengah-setengah. 
Berbeda dengan mainan anak tradisional, anak-anak dituntut kreatif sejak dalam proses pembuatannya yang harus berbaur dengan alam, karena bahan didapat dari lingkungan sekitar. Demikian pula saat memainkannya, selain dituntut kreatif juga harus memiliki strategi, kekuatan (tenaga), kebersamaan, kejujuran dan lainnya, yang berasal dari nilai-nilai kearifan lokal serta nilai-nilai tradisi yang merupakan benteng budaya.

Permainan anak tradisional tidak bisa dipandang hanya sebagai salah satu bentuk permainan semata. Banyak nilai-nilai filosofis dan kearifan lokal yang tertanam di sana. Permainan tradisi juga merupakan salah satu bentuk ketahanan budaya. Sebagai benteng ketahanan budaya, permainan anak (tradisional) masih cukup diminati, terutama oleh kelompokkelompok orang yang masih ingin mengenang masa lalunya.

Sejatinya permainan tradisional atau lebih dikenal dengan permainan rakyat merupakan sebuah kegiatan rekreatif yang tidak hanya bertujuan untuk menghibur diri, tetapi juga sebagai alat untuk memelihara hubungan dan kenyamanan sosial.

Permainan anak tradisional memiliki nilai pembelajaran bagi anakanak, seperti nilai ekonomi hingga demokrasi. Permainan Dakon atau Congklak, misalnya, dimaknai sebagai permainan yang mendidik anak agar rajin menabung dan bersikap ekonomis. Permainan ini menimbulkan hasrat anak untuk menemukan strategi mengumpulkan mata dakon, yang biasanya terbuat dari kulit kerang, sebanyak mungkin dalam wadah tabungan.
Sebagai sebuah benteng ketahanan budaya, permainan anak (tradisional) masih cukup diminati, terutama oleh kelompok-kelompok orang yang masih ingin mengenang masa lalunya, yang bisa dikatakan indah.

Melalui permainan tradisional atau permainan rakyat, anak-anak ataupun orang dewasa menunjukkan kerja sama dan kepiawaiannya dalam memainkan permainan tersebut. Di samping itu, juga nilai-nilai mental, seperti keadilan, penegakan aturan, kerja sama, hingga bentuk sanksi sosial bagi mereka yang "mencederai" aturan permainan yang harus ditaati oleh orang-orang yang memainkan permainan tradisional itu.

\section{PENUTUP}

Permainan dilakukan hanya untuk meyenangkan hati. Rasa senang dapat dialami oleh setiap orang, kaya atau miskin, orang kota atau desa dan berlaku dari dulu, sekarang, dan seterusnya sampai waktu tak terhingga. Pada masa anak-anaklah antusiasme permainan tak pernah surut, sehingga di masa ketika mereka baru mengenali permainan diharapkan mampu menangkap nilai-nilai dibalik suatu permainan.

Nilai-nilai luhur yang tersirat di dalamnya bisa melekat pada pemainpemainnya, yakni anak-anak yang kelak akan meneruskan perjuangan mempertahankan bangsa ini. Beberapa ahli psikologi berpendapat bahwa dalam permainan tradisional sangat besar pengaruhnya terhadap perkembangan jiwa anak. Dengan bermain bersama, anak-anak dilatih untuk bisa saling menghargai bahwa setiap orang memiliki karakter dan nasib yang 
berbeda-beda. Sesama manusia harus hidup tolong-menolong dengan bergotong-royong. Selain itu, pada setiap tahap permainan ini anak-anak sudah melatih diri untuk bersikap ulet, jujur, setia kawan, dan disiplin agar dapat mencapai apa yang dicitacitakan.

Permainan tradisional dapat mengasah kemampuan motorik anak, baik kasar maupun halus, serta gerak refleksnya. Selain gerakan motorik, anak juga dilatih bersikap cekatan, berkonsentrasi, dan melihat peluang dengan cepat untuk mengambil keputusan terbaik agar bisa menangkap lawan seperti dalam permainan Ucing Puntang. Kemudian permainan seperti Congklak dapat merangsang dalam menggunakan strategi. Anak harus pandai menentukan biji di lubang mana yang harus diambil terlebih dahulu, agar bisa mengumpulkan biji lebih banyak dari lawan.

Melihat manfaat-manfaat tersebut, sebenarnya permainan tradisional ini penting dilakukan oleh anak-anak zaman sekarang. Selain untuk memperoleh manfaat yang tidak bisa didapat dari permainan modern, juga untuk memacu anak lebih kreatif.

Permainan modern yang saat ini menjadi idola baru bagi anak-anak dinilai kurang mendidik, cenderung individual, materialistis, ingin menang sendiri, dan masih banyak efek negatif lainnya. Ironis memang, permainan modern yang sebagian besar berasal bukan dari negara sendiri, justru semakin digemari. Padahal, permainan tradisional dapat menjadi identitas warisan budaya bangsa di tengah keterpurukan kondisi bangsa saat ini.

Semakin berkurangnya lahan untuk bermain di daerah, menjadi titik awal minimnya anak-anak untuk memainkan permainan tradisional. Lahan terbuka yang selama ini sebagai ruang publik telah banyak tergusur. Padahal, permainan tradisional ini sama dengan olahraga rekreasi yang membutuhkan lahan luas, bahkan sudah diatur dalam Undang-Undang Olahraga Rekreasi. Tapi kalau lahan yang ada sekarang ini sudah terasa sempit, tentunya memainkan permainan tradisional akan terbatas pula.

Bagaimana akan melestarikan jika tidak tahu jenis-jenis permainan tradisional dan cara memainkannya. Kenyataan ini menjadi suatu tamparan bagi generasi sekarang yang telah banyak berubah seiring berkembangnya teknologi modern. Jika permainan tradisional tetap terjaga tentunya bisa menjadi daya tarik tersendiri bagi suatu daerah. Dengan menerapkan konsep ecotourism, dimana semua kebudayaan tradisional desa ditampilkan mulai dari permainan, tarian, hingga tradisi yang ada adalah sebuah langkah kongkret dalam melestarikan budaya tradisional. Dengan begitu, kebudayaan tradisional tidak akan digilas zaman karena dikemas dalam pertunjukan kebudayaan dan pariwisata.

\section{DAFTAR PUSTAKA}

Departemen Pendidikan dan Kebudayaan. 1982.

Permainan Anak-anak Jawa Barat. Bandung: IDKD Jawa Barat.

Departemen Pendidikan dan Kebudayaan. Sejarah Jawa Barat. Bandung: Proyek Penunjang Peningkatan Kebudayaan Nasional Provinsi Jawa Barat.

Djamaris, Edwar. 1977.

"Filologi dan Cara Kerja Penelitian Filologi." Bahasa dan Sastra Tahun III No. 1. Pusat 
Pembinaan dan Pengembangan Bahasa. Jakarta: Depdikbud.

Dundes. A. 1965.

The Study of Folklore. Englewood Cliffs, Prentice Hall.

Soekanto, Soerjono. 1982.
Sosiologi Suatu Pengantar. Jakarta: Rajawali.

Surakhmad, W. 1985.

Pengertian Penelitian Ilmiah. Bandung: Transito. 